\title{
Effect of Foliar Application of Zinc and Boron on Fruit Growth, Yield and Quality of Winter Season Guava (Psidium guajava L.)
}

\author{
Dewanshu Baranwal, Saurabh Tomar*, Jagendra Pratap Singh and \\ Jayant Kumar Maurya
}

\author{
Department of Horticulture, Chandra Shekhar Azad University of Agriculture and Technology \\ Kanpur 208002 (U.P.) India \\ *Corresponding author
}

\section{A B S T R A C T}

An experiment was conducted in 12 year old planted guava (Psidium guajava L.) garden at Kanpur (Uttar Pradesh) during the year 2014-15. The treatments comprised nine combinations of three $\mathrm{ZnSO}_{4}$ levels $(0.50,0.75,1.00 \%$ solution) and three borax levels

\section{Keywords}

Guava, Foliar spray,

Zinc, Boron,

Growth, Yield,

Quality.

\section{Article Info}

Accepted:

19 July 2017

Available Online:

10 September 2017 $(0.2,0.4,0.6 \%$ solution $)$ and one control of water spray. These 10 treatments were tested in factorial R.B.D. on guava. The results revealed that treated plants with $\mathrm{Zn}$ and Bo performed significantly much better than control of water spray in fruit growth, yield and quality traits. Among nutrient treatments, Zn So 4 @ $0.75 \%$ or borax @ $0.4 \%$ spray increased fruit set percentage significantly over $0.50 \% \mathrm{Zn} \mathrm{So}_{4}$ or $0.2 \%$ borax spray, respectively but fruit retention percentage was recorded significantly highest with $1.00 \%$ $\mathrm{Zn} \mathrm{So} \mathrm{So}_{4}$ or $0.6 \%$ borax solution spray. Fruit growth was influenced much by borax spray than $\mathrm{Zn} \mathrm{So}_{4}$. The spray of $0.6 \%$ borax solution produced biggest size of fruits with maximum weight and volume which contributed to highest fruit yield of $45.17 \mathrm{~kg} / \mathrm{plant} \mathrm{Zn}$ $\mathrm{So}_{4} @ 1.00 \%$ spray produced $44.10 \mathrm{~kg}$ fruit yield/plant. Borax spray @ $0.6 \%$ solution attained significantly maximum values of $8.25 \%$ total sugar, 12.04 TSS brix, and 186.92 mg Ascorbic acid per 100g fruit. The treatment of $\mathrm{Zn} \mathrm{So}_{4} @ 1.00 \%$ spray also recorded highest values of $6.83 \%$ total sugar, 11.64 TSS brix and $186.67 \mathrm{mg}$ Ascorbic acid per $100 \mathrm{~g}$ fruit but these values were found significantly higher only over $0.50 \% \mathrm{Zn} \mathrm{\textrm {So } _ { 4 }}$ spray treatment.

\section{Introduction}

Guava (Psidium guajava L.) is said to be the poor man's apple or the apple of tropics. Its nutritive values are very high, therefore, considered an ideal fruit for nutritional security. It is one of the cheapest and good source of vitamin ' $\mathrm{C}$ '. Guava is hardy fruit plant which can be grown in poor alkaline or poorly drained soils. It gives ripen fruits mainly in two seasons of rains and winter. The rainy season crop is rough, insipid, poor in quality and less nutritive, whereas winter season crop is superior in quality having long storage life and fetches more price in the market (Rathore and Singh, 1976). Being perishable nature of ripe fruit, it is essential to improve the quality of guava fruits which may be helpful in prolongation of shelf life of fruits. Several research workers have observed certain pre-harvest treatments which helped in improving the quality of fruits at harvest and enhanced the storage life by influencing the post-harvest changes 
(Chaitanya et al., 1997). Keeping into consideration the above points, the present study was undertaken on winter season guava crop of $\mathrm{Cv}$. Allahabad Safeda at Kanpur (U.P.).

\section{Materials and Methods}

The experiment was carried out in the guava garden of Horticulture Department, C.S. Azad University of Agric. and Tech., Kanpur during the year 2014-15. Soil of the garden is sandy loam, well drained, slightly alkaline in reaction having $7.98 \mathrm{pH}$. Twelve years old uniform guava plants planted at $6 \times 6 \mathrm{~m}$ space were selected for investigation. Nutrients application and other orchard management practices were followed as per recommended package of practices for guava plants. The treatments comprised nine combinations of three zinc levels $(0.50,0.75,1.00 \%$ spray of zinc sulphate) and three boron levels $(0.2,0.4$, $0.6 \%$ foliar spray of boric acid) along with one control (water spray). All ten treatments were tested in factorial Randomized Block Design replicated thrice. One plant was taken as unit per plot. First spraying of nutrients was done on $12^{\text {th }}$ September, 2014 (before first flowering) and the second spraying of nutrients was done on $12^{\text {th }}$ November, 2014 (after fruit setting). The foliar spraying of nutrient solution as per treatment was done through power sprayer fitted with flat-fan nozzle by using solution volume @ 10 liters per plant at each stage of spraying. The observations were recorded on plant growth, flowering and fruiting behaviour, physiochemical parameters of fruit and fruit yield. Plant growth was measured in terms of shoot length and number of leaves per shoot. As sample, ten shoots/plant and ten fruits/plant were selected randomly for concerning studies. The data collected on different crop characters were analyzed statistically in factorial randomized block design as suggested by Panse and Sukhatme (1985).

\section{Results and Discussion}

\section{Effect on plant growth, flowering and fruiting behaviour}

The data furnished in table 1 clearly indicate that treated plants with nutrient foliar spray performed significantly far better than control plants where only water spray was done. Among nutrient spray treatments, Zn $\mathrm{So}_{4} @$ $0.75 \%$ spray being at par with $\mathrm{Zn} \mathrm{So}_{4} @ 1.00$ solution spray improved shoot length and number of leaves per shoot significantly over

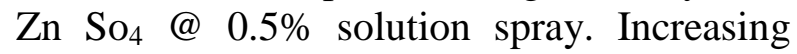
levels of boron had no significant effect on shoot length and number of leaves per shoot, thus borax@0.2\% solution spray was found sufficient for plant growth. However, higher levels of 0.4 and $0.6 \%$ borax spray reduced shoot length significantly as compared to $0.2 \%$ borax spray. These results are in agreement to those of El-Sharif et al., (2000).

Increasing levels of $\mathrm{Zn} \mathrm{So}_{4}$ solution spray increased number of flowers per shoot and fruit set percentage but margin of increase beyond $0.75 \% \mathrm{Zn} \mathrm{So}_{4}$ solution spray was not found significant on flowers per shoot or fruit set percentage but fruit retention percentage was found significantly highest with foliar spray of $1.00 \% \mathrm{Zn} \mathrm{So}_{4}$ solution. Increasing levels of borax spray also increased the number of flowers per shoot, fruit set and fruit retention percentage with upto highest level of $0.6 \%$ borax solution spray but margin of increase beyond $0.4 \%$ borax spray was not found significant on flowers per shoot and fruit set percentage, whereas fruit retention percentage was recorded highest with $0.6 \%$ borax solution spray. It might be due to the reason that these nutrients play an important role in translocation of carbohydrates and in auxin synthesis to the sink and increase pollen viability and fertilization. These results are in accordance to the findings of Raj Kumar et al., (2010). 
Table.1 Effect of foliar application of zinc and boron on growth, flowering and fruiting behaviour of guava

\begin{tabular}{|c|c|c|c|c|c|}
\hline \multirow[b]{2}{*}{ Treatments } & \multicolumn{2}{|c|}{ Growth } & \multicolumn{3}{|c|}{ Flowering behaviour } \\
\hline & $\begin{array}{c}\text { Shoot } \\
\text { length }(\mathbf{c m})\end{array}$ & $\begin{array}{l}\text { No. of } \\
\text { leaves per } \\
\text { shoot }\end{array}$ & $\begin{array}{c}\text { Flowers } \\
\text { per shoot }\end{array}$ & $\begin{array}{c}\text { Fruit set } \\
(\%)\end{array}$ & $\begin{array}{c}\text { Fruit } \\
\text { retention } \\
(\%)\end{array}$ \\
\hline \multicolumn{6}{|l|}{ Zinc levels } \\
\hline $\mathrm{Zn} \mathrm{So}_{4}(0.5 \%)$ & 119.33 & 44.66 & 58.79 & 60.98 & 45.43 \\
\hline $\mathrm{Zn} \mathrm{So}_{4}(0.75 \%)$ & 129.33 & 57.66 & 59.20 & 62.22 & 47.17 \\
\hline $\mathrm{Zn} \mathrm{So}_{4}(1.00 \%)$ & 133.00 & 57.33 & 59.87 & 62.93 & 52.55 \\
\hline S. Ed. \pm & 2.16 & 1.44 & 0.40 & 0.64 & 1.24 \\
\hline C.D. $(\mathrm{P}=0.05)$ & 4.59 & 3.05 & 0.85 & 1.36 & 2.62 \\
\hline \multicolumn{6}{|l|}{ Boron levels } \\
\hline Boron $(0.2 \%)$ & 134.66 & 55.33 & 58.68 & 60.70 & 46.10 \\
\hline Boron $(0.4 \%)$ & 123.33 & 48.00 & 59.22 & 62.12 & 47.02 \\
\hline Boron $(0.6 \%)$ & 123.66 & 56.33 & 59.96 & 63.30 & 52.03 \\
\hline S. Ed. \pm & 2.16 & 1.44 & 0.40 & 0.64 & 1.24 \\
\hline C.D. $(\mathrm{P}=0.05)$ & 4.59 & 3.05 & 0.85 & 1.36 & 2.62 \\
\hline \multicolumn{6}{|c|}{ Treatment v/s control } \\
\hline Treatment & 127.22 & 53.22 & 59.28 & 62.04 & 48.38 \\
\hline Control & 110.00 & 33.00 & 56.39 & 56.39 & 39.88 \\
\hline S.Ed. \pm & 2.79 & 1.86 & 0.26 & 0.82 & 1.59 \\
\hline C.D. $(\mathrm{P}=0.05)$ & 5.92 & 3.94 & 0.56 & 1.75 & 3.38 \\
\hline
\end{tabular}

Table.2 Effect of foliar application of zinc and boron on fruit characters, yield and quality of guava

\begin{tabular}{|c|c|c|c|c|c|c|c|c|}
\hline \multirow[b]{2}{*}{ Treatments } & \multicolumn{4}{|c|}{ Fruit characters } & \multirow{2}{*}{$\begin{array}{c}\text { Fruit } \\
\begin{array}{c}\text { Yield } \\
\text { (kg/ha) }\end{array}\end{array}$} & \multicolumn{3}{|c|}{ Fruit quality } \\
\hline & $\begin{array}{c}\text { Length } \\
\text { (cm) }\end{array}$ & $\begin{array}{c}\text { Width } \\
\text { (cm) }\end{array}$ & $\begin{array}{c}\text { Weight } \\
\text { (g) }\end{array}$ & $\begin{array}{c}\text { Volume } \\
\text { (cc) }\end{array}$ & & $\begin{array}{c}\text { Total } \\
\text { sugar } \\
(\%)\end{array}$ & $\begin{array}{c}\text { TSS } \\
\text { (Bricks) }\end{array}$ & $\begin{array}{c}\text { Ascorbic } \\
\text { acid } \\
\text { (mg/100) }\end{array}$ \\
\hline \multicolumn{9}{|l|}{ Zinc levels } \\
\hline $\mathrm{Zn} \mathrm{So}_{4}(0.5 \%)$ & 6.63 & 6.63 & 135.18 & 140.23 & 43.00 & 6.08 & 11.23 & 183.26 \\
\hline $\mathrm{Zn} \mathrm{So}_{4}(0.75 \%)$ & 6.69 & 6.50 & 135.49 & 141.46 & 43.76 & 6.47 & 11.34 & 185.02 \\
\hline $\mathrm{Zn} \mathrm{So}_{4}(1.00 \%)$ & 6.71 & 6.48 & 136.67 & 141.83 & 44.10 & 6.83 & 11.64 & 186.67 \\
\hline S. Ed. \pm & 0.04 & 0.04 & 0.64 & 0.50 & 0.20 & 0.20 & 0.12 & 1.15 \\
\hline C.D. $(\mathrm{P}=0.05)$ & 0.10 & 0.10 & 1.37 & 1.06 & 0.42 & 0.40 & 0.25 & 2.45 \\
\hline \multicolumn{9}{|l|}{ Boron levels } \\
\hline Boron $(0.2 \%)$ & 6.56 & 6.44 & 133.55 & 138.25 & 42.06 & 6.67 & 10.64 & 183.22 \\
\hline Boron $(0.4 \%)$ & 6.48 & 6.13 & 135.25 & 140.40 & 43.62 & 7.46 & 11.37 & 184.82 \\
\hline Boron $(0.6 \%)$ & 6.99 & 6.85 & 138.54 & 144.66 & 45.17 & 8.25 & 12.04 & 186.92 \\
\hline S. Ed. \pm & 0.04 & 0.04 & 0.64 & 0.50 & 0.20 & 0.20 & 0.12 & 1.15 \\
\hline C.D. $(\mathrm{P}=0.05)$ & 0.10 & .10 & 1.37 & 1.06 & 0.42 & 0.40 & 0.25 & 2.45 \\
\hline \multicolumn{9}{|c|}{ Treatment $\mathrm{v} / \mathrm{s}$ control } \\
\hline Treatment & 6.68 & 6.53 & 135.78 & 141.10 & 43.62 & 7.46 & 11.34 & 184.98 \\
\hline Control & 5.98 & 5.75 & 119.26 & 130.80 & 32.70 & 4.92 & 9.52 & 171.00 \\
\hline S.Ed. \pm & 0.06 & 0.06 & 0.83 & 0.65 & 0.26 & 0.21 & 0.15 & 1.49 \\
\hline C.D. $(\mathrm{P}=0.05)$ & 0.12 & 0.13 & 1.70 & 1.37 & 0.55 & 0.46 & 0.33 & 3.16 \\
\hline
\end{tabular}




\section{Effect on fruit characters and yield}

The data presented in table 2 revealed that foliar application of nutrients in general (treated) improved all fruit characters and yield significantly by larger margin over simple water spray (control) treatment. It might be attributed to the fact that Boron and Zinc appear to have indirect role in hastening the process of cell division and cell elongation which perhaps improved the size, weight and volume of fruits and finally the fruit yield per plant. Among nutrient spray treatments, increasing levels of $\mathrm{Zn} \mathrm{So}_{4}$ spray increased fruit weight, fruit volume and fruit yield per plant with upto $1.00 \% \mathrm{Zn} \mathrm{So}_{4}$ solution spray which was found at par with $0.75 \%$ solution spray of $\mathrm{Zn} \mathrm{So}_{4}$. Increasing levels of boron spray were found more effective on fruit characters and yield than $\mathrm{Zn} \mathrm{So}_{4}$ sprays. Fruit length, width, weight, volume and yield per plant were recorded significantly highest values with highest level of $0.6 \%$ borax solution spray. It is believed that boron improves the physiological activities of plant which might have improved size, weight, volume of fruits and ultimately higher fruit yield per plant. Besides, fruit yield per plant is also attributed to fruit retention percentage. Thus, fruit yield per plant seems to be the combined effect on single fruit weight and number of fruits per plant. These results corroborate with the findings of Prasad et al., (2005).

\section{Effect on fruit quality parameters}

The quality traits of guava viz. total sugar, total soluble solids and ascorbic acid were estimated significantly higher in treated plant fruits than control plants with water spray (Table 2). Among nutrient spray treatments, all quality parameters increased with increasing concentration of zinc or boron upto their highest levels of $1.00 \% \mathrm{Zn} \mathrm{So}_{4}$ or $0.6 \%$ borax solution spray. However, effect of increasing borax levels was found more than $\mathrm{Zn} \mathrm{So}_{4}$ in all cases. Highest level of $0.6 \%$ borax solution spray increased total sugar per cent by 23.7 and $11.8 \%$ TSS brix by 13.2 and $6.6 \%$ and Ascorbic acid by 2.0 and $0.9 \%$ over those with $0.2 \%$ and $0.4 \%$ borax solution sprays, respectively. In case of highest level of $1.00 \% \mathrm{Zn} \mathrm{So}_{4}$ solution spray, it could increase total sugar per cent by $12.3 \%$ and $6.4 \%$, TSS brixs by 3.7 and $1.0 \%$ and Ascorbic acid by 1.9 and $1.0 \%$ over 0.50 and $0.75 \% \mathrm{Zn} \mathrm{So}_{4}$ solution sprays, respectively where differences between $1.00 \%$ and $0.75 \%$ $\mathrm{Zn} \mathrm{So}_{4}$ solution sprays were not found significant in any case. It might be attributed to the fact that boron directly affects the photosynthesis activity of plant and helps in sugar transport. Besides, the boron also plays an important role in activating the synthesis of ascorbic acid. These results are in agreement with the findings of Awasthi and Lal (2009) and Yadav et al., (2011) in guava.

The results of present study may be concluded that foliar spray of Borax @ 0.6\% solution and of $\mathrm{Zn} \mathrm{So}_{4} @ 0.75 \%$ solution on guava plants twice i.e. once before first flowering and again after fruit setting are beneficial to get higher yield of quality fruits from winter season crop. This practice improved flowering, fruit set, fruit retention, fruit size, weight, volume, yield per plant and fruit quality parameters viz., total sugar, TSS and Ascorbic acid significantly over other practices of foliar nutrient application.

\section{References}

Awasthi, P., and Lal, S. 2009. Effect of calcium, boron and zinc foliar sprays on the yield and quality of guava (Psidium guajava L.). Pannagar Journal of Research, 7 (2): 223-225.

Chaitanya, C.G., Kumar G., Rana, B.L. and Mathew, A.K. (1997). Effect of foliar 
application of zinc and boron on yield and quality of guava Cv. L-49. Haryana Journal of Horticulture Science, 26 (12): 78-80.

El-Sherif, A.A., Saeed, W.T. and Nouman, U.F. (2000). Effect of foliar application of potassium and zinc on behaviour of Mantakhab El. Kantar guava trees. Bulletin Agriculture University Cario, 51 (1): 73-84.

Panse, V.G., and Sukhatme, P.V. (1985). Statistical Methods for Agriculture Workers. ICAR, New Delhi.

Prasad, B., Das, S., Chatterjree, D. and Singh, U.P. (2005). Effect of foliar application of urea, zinc and boron on yield of guava. Journal of Applied Biology, 15 (1): 44-47.
Rajkumar Tiwari, J.P. and Shant Lal, (2010). Effect of foliar application of zinc and boron on fruit yield and quality of winter season guava (Psidium guajava L.) Cv. Pant Prabhat. Annals of Agricultural Biology Research, 19 (1): 105-108.

Rathore, D.S., and Singh, R.N. 19976. Yield pattern in tree cropping patter of guava (Psidium guajava L.). Indian Journal of Horticulture, 33: 7-13.

Yadav, H.C., Yadav, A.L., Yadav, D.K. and Yadav, P.K. 2011. Effect of foliar application of micronutrients and $\mathrm{GA}_{3}$ on fruit yield and quality of rainy season guava (Psidium guajana $\mathrm{L}$.) $\mathrm{Cv}$. L-49. Plant Archives, 11 (1): 149-149.

\section{How to cite this article:}

Dewanshu Baranwal, Saurabh Tomar, Jagendra Pratap Singh and Jayant Kumar Maurya. 2017. Effect of Foliar Application of Zinc and Boron on Fruit Growth, Yield and Quality of Winter Season Guava (Psidium guajava L.). Int.J.Curr.Microbiol.App.Sci. 6(9): 1525-1529. doi: https://doi.org/10.20546/ijcmas.2017.609.186 